Kirkpatrick, R. J. (1981) In Kinetics of Geochemical Processes (A. C. Lasaga and R. J. Kirkpatrick, eds.). Mineral. Soc. Am. Washington, DC, 321-98.

Kohli, C. S., and Ives, M. B. (1972) J. Crystal Growth, 16, $123-30$.

Kuo, L.-C., and Kirkpatrick, R. J. (1983) EOS, Trans. Amer. Geophys. Union, 64, 349.

Lacmann, R., Franke, W., and Heimann, R. (1974) $J$. Crystal Growth, 26, 106-16, 117-21.

Lofgren, G. (1980) In Physics of Magmatic Processes (R. B. Hargraves, ed.). Princeton Univ. Press, 487551.

-(1983) J. Petrol. 24, 229-55.

Nicolas, A., and Prinzhofer, A. (1983) Ibid. 24, 288 306.

KEYWORDS: crystal growth, igneous rocks, magmas.
Scarfe, C. M., Takahashi, E., and Yoder, H. S. (1980) Carnegie Inst. Washington Yearb. 79, 290-6.

Schnorr, W. (1915) Z. Kristallogr. 54, 289-331.

Siesmayer, B., Heimann, R., Franke, W., and Lacmann, R. (1975). J. Crystal Growth, 28, 157-61.

Smith, F. J. (1963) Physical Geochemistry. AddisonWesley, Mass., 624 pp.

Tsukamoto, K., Abe, T., and Sunagawa, I. (1983) J. Crystal Growth, 63, 215-18.

Watson, E. B. (1982) Contrib. Mineral. Petrol. 80, 73-87.

Wells, A. F. (1946) Phil. Mag. 37, 605-30.

[Manuscript received 3 May 1984]

(C) Copyright the Mineralogical Society

\title{
Co-ordination of boron in sillimanite
}

ION-MICROPROBE analyses of six sillimanites associated with kornerupine show that the sillimanite can incorporate from 0.035 to $0.43 \mathrm{wt}$. \% $\mathrm{B}_{2} \mathrm{O}_{3}$ (Grew and Hinthorne, 1983). Boron appears to substitute for silicon concomitantly with $\mathrm{Mg}$ substitution for $\mathrm{Al}$ such that the atomic $\mathrm{Mg} / \mathrm{B}$ ratio is close to 0.5 . This substitution results in a deficiency of cationic charge, which Grew and Hinthorne (1983) attributed to a submicroscopic rearrangement of the sillimanite structure involving loss of oxygen. A possible substitution scheme is $2(\mathrm{~B}+x \mathrm{Mg}) \rightarrow 2(\mathrm{Si}+x \mathrm{Al})+(1+x) \mathrm{O}$, where $x \simeq 0.5$. In the present study, we have addressed the question of co-ordination of boron in sillimanite. As boron can occur in trigonal or tetrahedral coordination with oxygen, there is no compelling reason that $\mathrm{B}$ substitution for $\mathrm{Si}$ implies tetrahedral co-ordination for $\mathbf{B}$.

Two of the boron-bearing sillimanites analysed by Grew and Hinthorne (1983), samples E 2724 and 3083D from South India (these authors' samples no. 2 and 4), and a sillimanite from a pegmatite lacking borosilicate minerals from Antarctica, sample 556 (no. 8, see also Grew, 1980; Rossman et al., 1982), are in fragments suitable for single crystal infra-red studies. Spectra were obtained on (010) cleavage fragments $/ / c$ and $/ / a$ with a Perkin Elmer 180 spectrometer (fig. 1). Prominent absorption bands in the B-rich sillimanite E $2724\left(0.42 \% \mathrm{~B}_{2} \mathrm{O}_{3}\right)$ are centred at 1372,1327, 1281, 1244, and 1128 $\mathrm{cm}^{-1}$ in the $\mathrm{E} / / \mathrm{c}$ polarization and $1317 \mathrm{~cm}^{-1}$ in $\mathrm{E} / / a$. These bands, which are less conspicuous in the boron-poor sillimanite $3083 \mathrm{D}\left(0.035 \% \mathrm{~B}_{2} \mathrm{O}_{3}\right)$ and are weak or absent in the Antarctic sillimanite, lie in the range 1100 to $1450 \mathrm{~cm}^{-1}$ in which $\mathrm{BO}_{3}$ groups absorb (Moenke, 1974; Weir and Schroeder, 1964; Weir, 1966). Absorption due to $\mathrm{BO}_{4}$ groups lies in the 1180 to $800 \mathrm{~cm}^{-1}$ region. Unfortunately, this region is largely inaccessible under our experimental conditions due to the opacity of the samples at wave numbers below $1050 \mathrm{~cm}^{-1}$. We suggest that the observed spectral features between 1372 and $1128 \mathrm{~cm}^{-1}$ in the two boron-bearing sillimanites are due to $\mathrm{B}$ in threefold co-ordination. The $\mathrm{B}-\mathrm{O}$ polyhedron could be either a triangle in which the B is coplanar with the three oxygens, or a highly distorted tetrahedron, in which the B lies slightly out of the plane of the three closest oxygens and is weakly bonded to a fourth oxygen extended from the boron: $\mathrm{BO}_{3}-\mathrm{O}$.

The absorption features appear not to be caused by submicroscopic inclusions in sillimanite of borosilicates with $\mathrm{BO}_{3}$ groups such as grandidierite (which is present as a constituent in E 2724), tourmaline (present in 3083D), or dumortierite. M. A. Carpenter (written communication, 1983) has examined a small sample of sillimanite E 2724 with the transmitting electron microscope (TEM) and did not observe any submicroscopic features that could represent incipient exsolution of a B-rich 


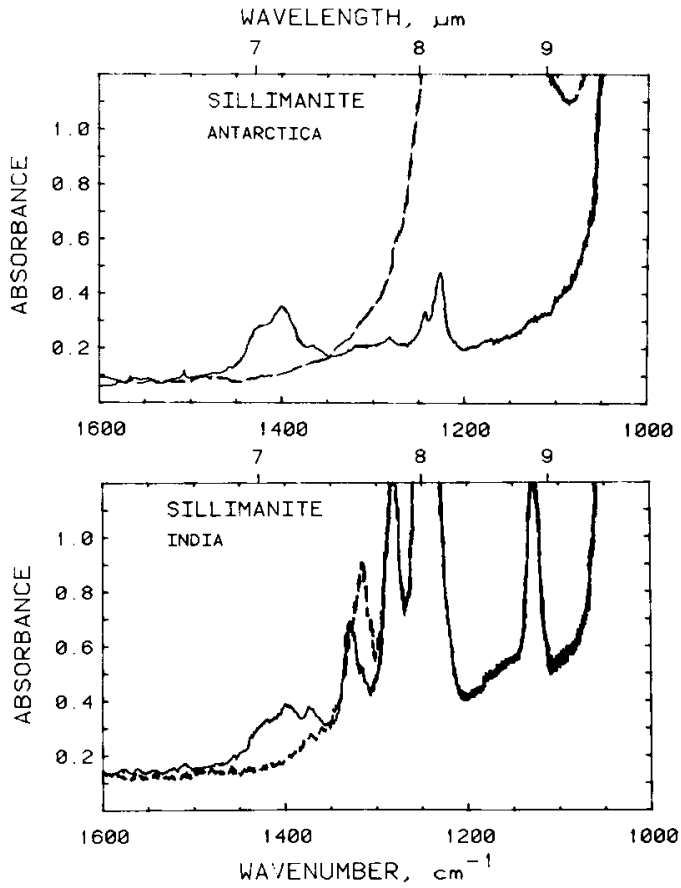

FlG. 1. Single crystal infra-red spectra of sillimanite (sample No. 556) from Reinbolt Hills, Antarctica (top) and of sillimanite (sample no. E 2724) from Paderu, India (bottom). Crystals about $34 \mu \mathrm{m}$ thick. Polarizations: solid line $\mathrm{E} / / c$; dashed line $\mathrm{E} / / a$.

phase from sillimanite. However, Carpenter cautions that isolated, widely dispersed inclusions of a B-rich phase would probably escape detection by the TEM. A further indication that the spectral features are caused by $B$ in the sillimanite is the correlation of their intensities with $\mathrm{B}_{2} \mathrm{O}_{3}$ contents analysed with the ion microprobe (Table I).

The pattern for the Antarctic sample indicates that traces of boron are present even in sillimanite from a rock lacking borosilicates. As Pearson and Shaw (1960) and Evers and Wevers (1984) report 20 to $180 \mathrm{ppm} \mathrm{B}$ (equivalent to 0.006 to $0.06 \mathrm{wt} \%$ $\mathrm{B}_{2} \mathrm{O}_{3}$ ) in sillimanite from environments not enriched in boron, it appears that sillimanite may in general contain traces of boron at the $0.0 \mathrm{X} \%$ $\left(\mathrm{B}_{2} \mathrm{O}_{3}\right)$ level.

The crystal-chemical mechanism by which B is incorporated in sillimanite remains an open question. The analytical data of Grew and Hinthorne (1983) suggest that B substitution is coupled with $\mathrm{Mg}$, the atomic $\mathrm{Mg} / \mathrm{B}$ ratio is close to 0.5 , and that sillimanites richer in boron $\left(0.30-0.43\right.$ wt. $\left.\% \mathrm{~B}_{2} \mathrm{O}_{3}\right)$ also contain significant $\mathrm{Fe}_{2} \mathrm{O}_{3}(1.29-1.39$ wt. \%).
T A BLE I. Intensity ratios of infra-red absorption features attributed to boron in sillimanite

\begin{tabular}{|c|c|c|c|}
\hline Sample no. locality & $\begin{array}{l}556 \\
\text { Antarctica }\end{array}$ & $\begin{array}{l}\text { 3083D } \\
\text { India }\end{array}$ & $\begin{array}{l}\text { E } 2724 \\
\text { India }\end{array}$ \\
\hline \multicolumn{4}{|l|}{ Absorption $\left(\mathrm{cm}^{-1}\right)$} \\
\hline 1244 & 0.239 & 1.0 & off scale \\
\hline 1281 & 0.376 & 1.56 & 10 \\
\hline 1128 & too weak & 1.49 & 10 \\
\hline \multirow[t]{2}{*}{1327} & - & 1.10 & 10 \\
\hline & wt. $\% \mathrm{~B}_{2} \mathrm{O}_{3}$ & & \\
\hline Infra-red* & 0.01 & 0.063 & 0.42 \\
\hline Ion Microprobe $\dagger$ & - & 0.035 & 0.42 \\
\hline
\end{tabular}

* Estimated from most reliable features and scaled to the $0.42 \% \mathrm{~B}_{2} \mathrm{O}_{3}$ analysed in $\mathrm{E} 2724$.

$\dagger$ Estimated precision is \pm 0.04 for E 2724 (Grew and Hinthorne, 1983).

Dash: not measured.

However, a B-bearing sillimanite from the kornerupine rock of Waldheim, Saxony, has an atomic $\mathrm{Mg} / \mathrm{B}$ ratio of 0.7 and contains only $0.33 \mathrm{wt} \%$ $\mathrm{Fe}_{2} \mathrm{O}_{3}$ (Table II). Thus oxidizing environments, which result in sillimanite $\mathrm{Fe}_{2} \mathrm{O}_{3}$ contents above 1 wt. \% (e.g. Grew, 1980), are not essential for B incorporation in sillimanite. Moreover, $\mathbf{B}$ incorporation in sillimanite appears not to involve hydroxyl, for none was detected in an infra-red trace from 3000 to $4000 \mathrm{~cm}^{-1}$ obtained on a slice of E $2724100 \mu \mathrm{m}$ thick (sensitivity, $0.01 \% \mathrm{H}_{2} \mathrm{O}$ ).

T A B LE II. Composition of sillimanite from Waldheim kornerupine rock (sample no. 5105c)

\begin{tabular}{lrl}
\hline & Weight \% & $\begin{array}{l}\text { Recalculated } \\
\text { to three cations }\end{array}$ \\
\hline $\mathrm{SiO}_{2}$ & 35.96 & 0.978 \\
$\mathrm{Al}_{2} \mathrm{O}_{3}$ & 62.02 & 1.988 \\
$\mathrm{Cr}_{2} \mathrm{O}_{3}$ & 0.09 & 0.002 \\
$\mathrm{Fe}_{2} \mathrm{O}_{3}$ & 0.33 & 0.007 \\
$\mathrm{MgO}$ & 0.27 & 0.011 \\
$\mathrm{~B}_{2} \mathrm{O}_{3}$ & 0.32 & 0.015 \\
Total & 98.99 & 3.0 \\
\hline
\end{tabular}

Electron microprobe analysis, except boron, which was analysed with ion microprobe by method of Grew and Hinthorne (1983). $\mathrm{TiO}_{2}, \mathrm{MnO}, \mathrm{Na}_{2} \mathrm{O}, \mathrm{K}_{2} \mathrm{O}$, and $\mathrm{CaO} \leqslant$ $0.03 \%$. 
Fluorine was not detected with the ion microprobe in any of the sillimanites analysed by Grew and Hinthorne (1983) or in the Waldheim sillimanite. One mechanism for $\mathbf{B}$ incorporation as $\mathrm{BO}_{3}$ or $\mathrm{BO}_{3}-\mathrm{O}$ groups is rearrangement of the sillimanite structure in the immediate vicinity of the boron-oxygen group to resemble the grandidierite stucture, $\left(\mathrm{Mg}, \mathrm{Fe}^{2+}\right)^{\mathrm{V}} \mathrm{Al}^{\mathrm{V}} \mathrm{Al}_{2}^{\mathrm{VI}} \mathrm{Si}^{\mathrm{IV}} \mathbf{B}^{\mathrm{III}} \mathrm{O}_{9}$, which was refined by Stephenson and Moore (1968). McKie (1965) first noted that sillimanite and grandidierite have similar cell dimensions. However, Stephenson and Moore (1968) suggested that the grandidierite structure was more closely related to andalusite, a suggestion consistent with infra-red data (Povarennykh, 1970).

The structures of grandidierite and sillimanite contain chains of $\mathrm{AlO}_{6}$ octahedra parallel to $c$ and have a nearly identical $c$ axis repeat $(5.760 \AA$ for grandidierite, McKie, 1965 , vs. $5.7774 \AA$ for sillimanite and $5.5566 \AA$ for andalusite, Winter and Ghose, 1979). Moreover, sillimanite and grandidierite have similar dimensions perpendicular to $c$, if structurally equivalent directions are compared, as suggested by McKie (1965) and Stephenson and Moore (1968). These are $a$ and $b$ of grandidierite, which are $10.335 \AA$ and $10.978 \AA$, respectively $v s$. the diagonals [110] and [1T0] in $\mathrm{Al}_{2} \mathrm{SiO}_{5}$, which are $10.727 \AA$ in sillimanite and $11.103 \AA$ in andalusite. Consequently, the dimensions of half a grandidierite unit cell are closer to the unit cell dimensions of sillimanite than to those of andalusite. Despite the differences in crystal structure discussed by Stephenson and Moore (1968), a unit cell of grandidierite might fit with little adjustment into a space occupied by four contiguous half unit cells of sillimanite. This mechanism would explain the loss of oxygen noted by Grew and Hinthorne (1983). Grandidierite has only nine oxygens for six cations compared to ten for $\mathrm{Al}_{2} \mathrm{SiO}_{5}$, so that $\mathrm{B}+\mathrm{Mg} \rightarrow$ $\mathrm{Si}+\mathrm{Al}+\mathrm{O}$ and $x=1$ (see above). As $x<1$ for the seven B-bearing kornerupines analysed to date, we considered the possibility that $\mathrm{Fe}^{2+}$ might be involved in the substitution. $\mathrm{No} \mathrm{Fe}^{2+}$ was detected spectroscopically in sample E 2724 in the 400 to $1200 \mathrm{~nm}$ region. If we assume a molar absorbtivity for $\mathrm{Fe}^{2+}$ of three, the sensitivity limit for $\mathrm{Fe}^{2+}$ content would be 0.07 wt. $\%(0.002$ per formula unit of three cations), an upper limit, as the molar absorbtivity is undoubtedly higher. Consequently, we doubt that sufficient $\mathrm{Fe}^{2+}$ is present in sillimanite to bring the $\left(\mathrm{Mg}+\mathrm{Fe}^{2+}\right) / \mathrm{B}$ ratio to unity, the value in grandidierite. Possibly the rearranged part of sillimanite does not correspond to a full unit cell of grandidierite, resulting in $\mathrm{Mg} / \mathrm{B}$ less than unity.

Our infra-red data are consistent with the orientation of $\mathrm{BO}_{3}$ groups in a grandidierite segment oriented such that the $c$ axis of grandidierite is parallel to the $c$ axis of sillimanite, and $a$ or $b$ of grandidierite parallel to [110] of sillimanite. Thus the $\mathrm{BO}_{3}$ groups, which are oriented nearly parallel to (010) in grandidierite (Stephenson and Moore, 1968 ), would lie roughly parallel to (110) in sillimanite. In grandidierite two $\mathrm{B}-\mathrm{O}$ bonds make a small angle to $c$, while the third is perpendicular. This orientation could result in the abundant absorption features in $E / / c$ and fewer features in $\mathrm{E} / / \mathrm{a}$ present in our patterns. However, of the four sharp bands von Knorring et al. (1969) and Povarennykh (1970) attributed to trigonal boron in spectrometer tracings of powdered grandidierite, namely $1465-1458 \mathrm{~cm}^{-1}$ (medium intensity), 1415 $1407 \mathrm{~cm}^{-1}$ (strong), $1375-1370 \mathrm{~cm}^{-1}$ (medium), and $1315-1308 \mathrm{~cm}^{-1}$ (strong), only two are close to bands in the sillimanite pattern, namely $1372 \mathrm{~cm}^{-1}$ (weak) and $1327-1317 \mathrm{~cm}^{-1}$ (medium). The presence of bands below $1300 \mathrm{~cm}^{-1}$ and absence of bands above $1400 \mathrm{~cm}^{-1}$ in the sillimanite pattern indicates a somewhat different environment for boron in sillimanite, which might result if the $\mathrm{BO}_{3}$ groups were not strictly planar and the boron were weakly co-ordinated to a fourth oxygen.

Acknowledgements. We thank R. I. Gait for sample E 2724 from the collection of the Royal Ontario Museum, Toronto; K. Abraham (Bochum) and N. Marquez (Aerospace Corporation, Los Angeles) for assistance with the electron and ion microprobe analyses; G. Mathé and J. Hofmann (Freiberg) for guidance to the Waldheim locality, M. A. Carpenter (Cambridge) for the TEM work, and W. Schreyer (Bochum) for comments. Grew's research at Bochum was supported by the Alexander von Humboldt-Stiftung (Bonn) and Rossman's research in part by US National Science Foundation Grant EAR-79. 19987.

\section{REFERENCES}

Evers, T. J. J. M., and Wevers, J. M. A. (1984) Neu. Jahrb. Mineral. Mh. 49-60.

Grew, E. S. (1980) J. Petrol. 21, 39-68.

and Hinthorne, J. R. (1983) Science, 221, 547-9.

McKie, D. (1965) Mineral. Mag. 34, 346-57.

Moenke, H. H. W. (1974) in The Infrared Spectra of Minerals (V. C. Farmer, ed.). Mineralogical Society Monograph 4, 365-82.

Pearson, G. R., and Shaw, D. M. (1960) Am. Mineral. 45, $808-17$

Povarennykh, A. S. (1970) Bull. Soc. Franc. Mineral. Cristallogr. 93, 224-34.

Rossman, G. R., Grew, E. S., and Dollase, W. A. (1982) Am. Mineral. 67, 749-61.

Stephenson, D. A., and Moore, P. B. (1968) Acta Crystallogr. B 24, 1518-22.

von Knorring, O., Sahama, T. G., and Lehtinen, M. (1969) Bull. Geol. Soc. Finland, 41, 71-4. 
Weir, C. E. (1966) J. Research U.S. Nat. Bur. Standards

(Phys. Chem.) 70A, 153-64.

and Schroeder, R. A. (1964) Ibid. 68A, 465-87.

Winter, J. K., and Ghose, S. (1979) Am. Mineral. 64, $573-86$.

KEYWORDS: ion microprobe, boron, sillimanite.

Institut für Mineralogie, Ruhr-Universität Bochum, [Manuscript received 17 April 1984; revised 2 August 1984]

C) Copyright the Mineralogical Society

Postfach 1021 48, D-4630 Bochum 1, West Germany

Division of Geological and Planetary Sciences,

EDWARD S. GREW

California Institute of Technology, ${ }^{*}$ Pasadena, California 91125, USA

GeORGE R. RoSSMAN

* Contribution 4702.

MINERALOGICAL MAGAZINE, MARCH 1985, VOL. 49, PP. 135-137

\section{Pekoite from Narechen, Bulgaria - a possible solution to the bonchevite problem}

A NUMBER of $\mathrm{Pb}-\mathrm{Bi}-\mathrm{S}$ minerals, including bonchevite (Kostov, 1958), galenobismutite and lillianite (Kupcik et al., 1969), have been recorded from scheelite-bearing quartz veins near the town of Narechen, in the Southern Rhodope Mountains, Bulgaria. The quartz veins are up to $0.5 \mathrm{~m}$ thick and cut muscovite-biotite schists of the Rhodopian Complex (Bonev, 1982). One of the authors (W.D.B.) collected several specimens of quartz from a vein north of Narechen during the International Mineralogical Association excursion in September 1982. The specimens contain thin bladed crystals, up to $1 \mathrm{~mm}$ wide and $2 \mathrm{~cm}$ long of a soft, steel-grey mineral which gave an X-ray powder diffraction pattern close to that of bismuthinite. However, long-exposure Weissenberg X-ray films taken of a small fragment of the mineral revealed weak superlattice spots characteristic of pekoite (Mumme and Watts, $1976 a, b)$. Several small fragments from the same X-rayed crystal were mounted, polished, and examined under reflected light. The pekoite was very weakly pleochroic, cream in colour, and strongly anisotropic. The prismatic crystals were made up of a mosaic of grains elongated roughly parallel to a well-defined 010 cleavage. No inclusions were observed.

Electron microprobe analyses (Table I), obtained from the same fragments, show a range in composition within a single crystal, deviating from the standard formula for pekoite $\left(\mathrm{PbCuBi}_{11} \mathrm{~S}_{18}\right)$. The mole $\%$ of $\mathrm{Bi}_{2} \mathrm{~S}_{3}$ ranges from 74 to 83 , largely within the pekoite compositional field reported by Harris
T A B LE I. Electron microprobe analyses (in wt. $\%$ ) of pekoite from Narechen, Bulgaria

\begin{tabular}{lrrrrrr}
\hline & \multicolumn{1}{c}{1} & \multicolumn{1}{l}{2} & \multicolumn{1}{l}{3} & \multicolumn{1}{l}{5} & \multicolumn{1}{l}{6} \\
\cline { 1 - 4 } $\mathrm{Cu}$ & 2.41 & 1.71 & 1.75 & 1.59 & 1.52 & 1.59 \\
$\mathrm{~Pb}$ & 8.31 & 5.98 & 5.68 & 5.26 & 5.25 & 5.20 \\
$\mathrm{Bi}$ & 70.44 & 73.56 & 74.04 & 74.55 & 74.81 & 74.36 \\
$\mathrm{~S}$ & 17.32 & 17.35 & 17.63 & 17.48 & 17.64 & 17.69 \\
Total & 98.48 & 98.60 & 99.10 & 98.88 & 99.22 & 98.84 \\
Formulae & $(\mathrm{S}=18.00)$ & & & & \\
$\mathrm{Cu}$ & 1.27 & 0.90 & 0.92 & 0.83 & 0.79 & 0.82 \\
$\mathrm{~Pb}$ & 1.33 & 0.96 & 0.88 & 0.83 & 0.82 & 0.82 \\
$\mathrm{Bi}$ & 11.23 & 11.71 & 11.59 & 11.79 & 11.72 & 11.61 \\
$\mathrm{~S}$ & 18.00 & 18.00 & 18.00 & 18.00 & 18.00 & 18.00 \\
\hline
\end{tabular}

Notes. Analysis was by a JEOL microprobe with a beam voltage of $20 \mathrm{kV}$ and a specimen current of $0.018 \mu \mathrm{A}$. Standards used were pure metals ( $\mathrm{Bi}, \mathrm{Cu}, \mathrm{Sb}, \mathrm{Ag}, \mathrm{Zn}, \mathrm{Fe})$ troilite $(\mathrm{S})$, and galena $(\mathrm{Pb}) \mathrm{Sb}$, $\mathrm{Ag}, \mathrm{Fe}$, and $\mathrm{Zn}$ were below detection limits at all points analysed. (Analyst: W. Birch.)

and Chen (1976). The increase in $\mathrm{Bi}$ is matched by a decrease in $\mathrm{Cu}$ and $\mathrm{Pb}$, but with the $\mathrm{Cu} / \mathrm{Pb}$ ratio remaining close to unity. These data are plotted in the $\mathrm{Cu}_{2} \mathrm{~S}-\mathrm{PbS}-\mathrm{Bi}_{2} \mathrm{~S}_{3}$ system in fig. 1 .

The physical and optical properties of the Narechen pekoite are similar to those of the incompletely characterized mineral bonchevite, as described from Narechen by Kostov (1958). On the basis of the X-ray powder diffraction data, Kostov suggested that the mineral was related to galenobismutite and bismuthinite. However, Fleischer 